\title{
RELASI KONSTITUSI DENGAN USAHA TANI IKAN, SAYUR, TELUR ORGANIK DAN NON-ORGANIK GUNA MENDUKUNG EKONOMI MASYARAKAT DAN WILAYAH ( STUDI KASUS DI KECAMATAN BANTUR KABUPATEN MALANG )
}

\author{
Sri Mulyaningsih \\ Ghozali Maski \\ Devanto Shasta Pratomo \\ Fakultas Ekonomi \& Bisnis Universitas Brawijaya
}

\begin{abstract}
Agribusiness is still the pillar for farmers' economy in Indonesia who, mostly, work for agricultural sector. This also applies in regional economy in which agricultural sector is the primary sector that becomes the basis for economy and gives sufficient contribution to the regional economic development. However, the condition of the farmers' economy has so far shown no significant development. The Constitution (UUD 1945) regulates national economy that embraces any fields, including the sustainable and environment-oriented agriculture, aiming at society's prosperity in both economy and health. The research shows that there is no difference on benefit between organic and non-organic agribusiness on fish, vegetable, eggs. Thus agribusiness is better developed conforming to the Constitution that signals environment-oriented agriculture.
\end{abstract}

Keywords: agribusiness, constitution, economic basis, environment-oriented.

\section{A. LATAR BELAKANG}

Berdasarkan UUD 1945 pasal 33, ayat 4 menyatakan "Perekonomian nasional diselenggarakan berdasar atas demokrasi ekonomi dengan prinsip kebersamaan, efisiensi berkeadilan, berkelanjutan, berwawasan lingkungan, kemandirian, serta dengan menjaga keseimbangan kemajuan dan kesatuan nasional". Perlu digaris bawahi bahwa kegiatan pembangunan disegala bidang termasuk bidang pertanian mengacu pada UUD 1945 yaitu mengandung muatan agar berwawasan lingkungan. Adapun tujuannya untuk keamanan lingkungan dan kesejahteraan masyarakat termasuk kesehatan.Hal ini termasuk upaya untuk meningkatkan kualitas hidup, seperti tertuang dalam UUD 1945 pasal 28 C ayat 1.

Jumlah penduduk miskin, yaitu sekitar 30 juta dari 179 juta penduduknya masih hidup dalam kemiskinan absolut dan sebagian besar dari jumlah penduduknya yang dikategorikan agak miskin mempunyai pendapatan hanya sedikit diatas garis kemiskinan (World Bank,1990). Apalagi di saat krisis ekonomi setelah tahun 1997 disinyalir jumlah penduduk yang miskin di Indonesia bertambah. Mengingat Indonesia adalah negara agraris, dengan demikian cocok untuk mengembangkan usaha tani terpadu yang aman buat lingkungan. 
Mayoritas penduduk bergerak di sektor pertanian yang merupakan warisan nenek moyang. Oleh karena itu potensi tersebut perlu dilestarikan dan ditingkatkan produktivitasnya. Apabila kondisi kesuburan lahan mengalami penurunan, yang ditengarahi penggunaan pupuk kimia sintetis yang sudah dalam posisi diminishing return. Dengan demikian pertanian organik di masa depan diharapkan dapat meningkatkan produktivitas dengan lahan yang diperbaiki kesuburannya. Sistem pertanian organik secara terpadu akan lebih efisien dan menjamin keberlanjutannya (sustainability).

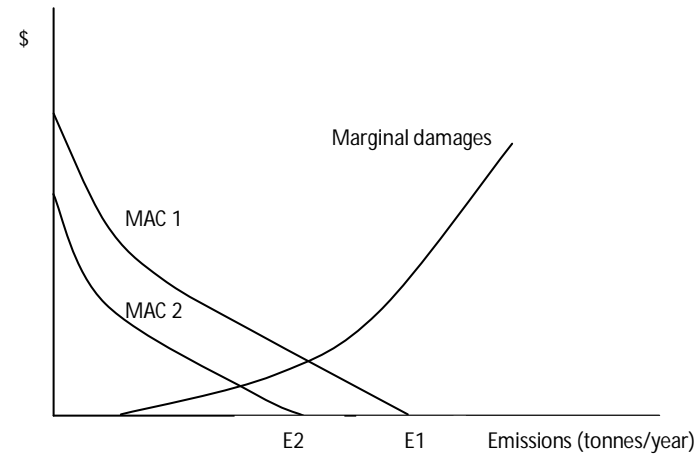

Gambar 1. Pengaruh green goods terhadap kurva biaya marginal

Sumber: Field \& Olewiler, 2002

Penelitian ini menggali potensi sektor pertanian dan mencoba meninjau prospek pertanian organik berdasarkan hasil penelitian "Sistem Produksi Sayuran Ternak Ikan Organik Berbasis Pada Limbah Organik", merupakan Program Insentif Percepatan Difusi dan Pemanfaatan IPTEK, dilakukan oleh Lembaga Penelitian Universitas Brawijaya dan Kementrian Negara Riset dan Teknologi Republik Indonesia tahun 2007. Daerah penelitian tersebut di Kabupaten Malang, khususnya di Kecamatan Bantur. Sehingga tujuan dari artikel ini adalah mengidentifikasi potensi sektor pertanian di Kecamatan Bantur dan Kabupaten Malang; menganalisis perbedaan hasil usaha tani organik terpadu (sayuran, ternak,ikan) dengan non-organik; melihat prospek ekonomi pertanian organik di masa depan.

\section{B. KAJIAN TEORITIS}

\section{Konsep Valuasi Ekonomi}

Definisi nilai ekonomi adalah "sebagai pengukuran jumlah maksimum seseorang ingin mengorbankan barang dan jasa untuk memperoleh barang dan jasa lainnya" (Fauzi, 2006:209). Demikian pula konsep opportunity cost yang merupakan biaya peluang dalam menentukan suatu pilihan terhadap barang dan jasa. Untuk menentukan pilihan seseorang menggunakan konsep analisis manfaat-biaya (benefit-cost analysis). Perlu diketahui bahwa konsep CBA yang konvensional tidak memasukkan pertimbangan manfaat ekologis. Oleh karena itu CBA yang digunakan dalam konsep sistem pertanian organik terpadu ini telah memasukkan manfaat 
ekologis, yang disebut green goods. Apabila masyarakat memproduksi dan mengkonsumsi green goods berarti telah mempunyai andil untuk menyelamatkan lingkungan. Hal ini seperti di tunjukkan dalam gambar 1, yaitu menunjukkan bahwa green goods dapat mengurangi pencemaran. Dengan demikian terjadi pengurangan biaya untuk menanggulangi pencemaran lingkungan. Berdasarkan hasil rekap dari buku Enviromental Economics (Field \& Olewiler, 2002:202) "Production and consumption of green goods lowers the pollution intensity of an economy's output (shifts the MAC curve down), and leads to higher levels of enviromental quality".

Pada prinsipnya manusia senantiasa dihadapkan dengan suatu pilihan untuk menentukan konsumsi dan produksi yang akan diusahakan/diadakan. Berdasarkan teori ekonomi mikro, biaya peluang (opportunity cost) menggunakan sesuatu dalam suatu usaha tertentu merupakan manfaat yang dikorbankan (atau kehilangan peluang) karena tidak menggunakan barang itu pada alternative penggunaan yang terbaik. Sedangkan untuk mengukur biaya peluang, perusahaan harus membebankan setiap input yang telah digunakannya, dalam nilai moneter yang setara dengan yang telah dikorbankan untuk memperoleh input tersebut (Lipsey, 1995 : 237-238).

Pada kenyataannya, biaya peluang tidak hanya untuk diterapkan dalam ilmu ekonomi, namun juga di luar ilmu ekonomi. Hal ini tergantung berbagai pertimbangan di luar ilmu ekonomi yang di contohkan dalam bukunya Lipsey berikut:

Pensiunan Jenderal Robert Russ memutuskan untuk menyumbangkan uang sebesar 5.000 dolar kepada kebun binatang lokal. Pengacaranya memberitahu bahwa karena sumbangan seperti ini dapat dikurangi dari pendapatan kena pajak, biaya sebenarnya dari sumbangan ini sama seolah ia memberikan uang ekstra sebesar 3.450 dolar kepada putra tirinya yang pemboros. Apakah biaya peluang dari sumbangannya kepada kebun binatang 5.000 dolar atau 3.450 dolar?

George Bernard Shaw, menjelang hari ulang tahun yang kesembilan puluh, ditanya bagaimana rasanya berusia 90. Ia menjawab "Baik-baik saja, jika anda melihat alternative lainnya" (Lipsey, 1995).

\section{Pengertian Pertanian Organik}

Menurut para pakar pertanian Barat sistem pertanian organik merupakan hukum pengembalian (law of return) yang berarti suatu sistem yang berusaha untuk mengembalikan semua jenis bahan organik ke dalam tanah, baik dalam bentuk residu dan limbah pertanaman maupun ternak yang selanjutnya bertujuan memberikan makanan pada tanaman. Filosofi yang melandasi pertanian organik adalah mengembangkan prinsip-prinsip memberikan makanan pada tanah yang selanjutnya tanah menyediakan makanan untuk tanaman (feeding the soil that feeds the plants) dan bukan memberi makanan langsung pada tanaman (Sutanto, 2002).

Menurut IFOAM (International Federation of Organik Agriculture Movements) didefinisikan sebagai sistem produksi pertanian yang holistik dan terpadu, dengan cara mengoptimalkan kesehatan dan produktivitas agro-ekosistem secara alami, sehingga menghasilkan pangan dan serat yang cukup, berkualitas dan berkelanjutan. Pertanian organik adalah sistem pertanian yang holistik yang mendukung dan mempercepat biodiversity, siklus biologi dan aktivitas biologi tanah. Menurut International Federation Organic Agriculture Movement (1990) mempunyai 11 prinsip (Sutanto : 2002) ialah: 
a. Melalui pertanian organic dihasilkan makanan dengan kualitas nutrisi yang tinggi dan dalam jumlah yang cukup.

b. Melaksanakan interaksi yang bersifat sinergisme dengan system dan daur ulang alami yang mendukung semua bentuk kehidupann yang ada.

c. Mendorong dan meningkatkan daur ulang dalam sistem usaha tani dengan mengaktifkan kehidupan biologi (flora dan fauna tanah), tanaman dan hewan,

d. Memelihara dan meningkatkan kesuburan tanah secara berkelanjutan,

e. Memanfaatkan sumberdaya terbarukan (renewable resources) yang berasal dari sistem usaha tani itu sendiri

f. Memamfaatkan bahan-bahan yang mudah didaur ulang, baik di dalam maupun di luar usaha tani,

g. Menciptakan keadaan yang memungkinkan ternak melaksanakan gatra dasar sesuai habitatnya,

h. Membatasi terjadinya bentuk pencemaran akibat kegiatan pertanian

i. Memperhatahankan keanekaragaman hayati, termasuk pelestraian habitat tanaman dan hewan

j. Memberikan jaminan pada produsen (petani) sesuai hak asasi manusia dalam memenuhi kebutuhan dasar serta memperoleh penghasilan dan kepuasan dari pekerjaannya, termasuk lingkungan bekerja yang aman, dan

k. Mempertimbangkan dampak yang lebih luas kegiatan usaha tani terhadap kondisi lingkungan fisik dan sosial.

\section{Perubahan Regional dan Teori Basis Ekonomi}

Perekonomian regional dapat dibagi menjadi dua sektor yaitu kegiatan basis dan bukan basis. Kegiatan basis adalah kegiatan-kegiatan yang mengekspor barang-barang dan jasa ke tempat-tempat diluar batas-batas perekonomian masyarakat yang bersangkutan, atau yang memasarkan barang-barang dan jasa-jasa mereka pada orang-orang yang datang dari luar perbatasan perekonomian masyarakat yang bersangkutan. Kegiatan bukan basis adalah kegiatankegiatan yang menyediakan barang-barang yang dibutuhkan oleh orang-orang yang bertempat tinggal didalam batas-batas perekonomian masyarakat yang bersangkutan. Kegiatan-kegiatan ini tidak mengekspor barang-barang jadi, luas lingkup produksi mereka dan daerah pasar mereka yang terutama adalah bersifat lokal.

Pendekatan secara tidak langsung mengenai pemisahan antara kegiatan basis dapat menggunakan salah satu ataupun gabungan dari tiga metode, walaupun tidak satupun diantara yang seluruhnya memuaskan:

1. Menggunakan asumsi-asumsi atau metode arbriter sederhana yang mengasumsikan bahwa semua industri primer dan manufakturing adalah basis, dan semua industri jasa adalah bukan basis metode ini tidak memperhitungkan adanya kenyatan bahwa dalam kelompok industri bisa terdapat industri atau industri-industri yang menghasilkan barang-barang yang sebagian diekspor atau dijual secara lokal ataupun dua-duanya.

2. Metode kedua, yaitu metode kuosien lokasi (location quotiens/LQ), mempero-leh sambutan yang lebih besar dalam kalangan akademi, tetapi mempunyai realibilitas yang tidak jauh 
lebih besar dari pada metode pertama. Akan tetapi, beberapa dari asumsi-asumsi yang mendasarinya, seperti keseragaman pola-pola permintaan regional dan nasional dan kesempatan produktifitas regional menurut sektor industri, melemahkan realibiltasnya.

LQ dapat dihitung dari rumus matematis:

$$
L Q=\frac{S i / N i}{S / N}=\frac{S i / S}{N i / N}
$$

Keterangan :

$\mathrm{Si}$ : Besaran dari suatu kegiatan tertentu yang akan diukur di daerah yang ditelaah.

$\mathrm{Ni}$ : Besaran total untuk kegiatan tertentu dalam daerah yang lebih luas.

$\mathrm{S}$ : Besaran total untuk seluruh kegiatan di daerah yang diteliti (ditelaah).

$\mathrm{N}$ : Besaran total untuk seluruh kegiatan di daerah yang lebih luas.

Ukuran/besaran yang dapat dipakai antara lain tenaga kerja dan hasil produksi dari sektor kegiatan. Metode ini berguna untuk menunjukkan dominasi dan peranan suatu sektor kegiatan dalam lingkup daerah tertentu. Hal ini ditunjukkan oleh besarnya nilai LQ, dimana rasio yang lebih besar dari pada 1 (LQ>1)menunjukkan kegiatan ekspor atau basis, dan jumlah pekerja yang merupakan selisih dari jumlah yang diperlukan untuk mencapai LQ = 1 (yakni yang melebihi jumlah yang diperlukan untuk mencapai swasembada regional) dianggap sebagai tenaga kerja yang melayani pasar ekspor. Rasio LQ yang lebih kecil dari pada 1 (LQ < 1) menunjukkan kegiatan kegiatan lokal atau bukan basis. Metode ini mempunyai beberapa kebaikan. Ia memperhitungkan penjualan barang-barang antara (dengan demikian, industri batubara lokal yang menjual batubaranya kepada industri baja lokal akan digolongkan sebagai basis jika LQ > 1), tidak mahal biayanya dan mudah diterapkan

\section{METODE PENELITIAN DAN ANALISIS DATA}

\section{Analisis Data Kuantitatif (Statistik)}

Analisis Statistik menggunakan Anova, yaitu analisi varian. Analisis statistik menggunakan metode Anova termasuk analisis komparatif (perbandingan) lebih dari dua rata-rata. Tujuan dari uji Anova satu jalur adalah untuk membandingkan lebih dari dua rata-rata. Sedangkan gunanya untuk menguji kemampuan generalisasi. Maksudnya dari signifikasi hasil penelitian (anova satu jalur). Jika terbukti berbeda berarti kedua sampel tersebut dapat digeneralisasikan. Langkahlangkah uji anova satu jalur:

a. Sebelum anova dihitung, asumsikan bahwa data dipilih secara random, berdistribusi normal, dan variannya homogen.

b. Buatlah hipotesis (H1 dan Ho) dalam bentuk kalimat.

c. Buatlah hipotesis (H1 dan Ho) dalam bentuk statistik.

d. Daftar statistik induk

e. Menghitung jumlah kuadrat antar group 
f. Menghitung kuadrat rerata antar group

g. Menghitung jumlah kuadrat dalam antar group

h. Menghitung derajat bebas dalam group.

i. Menghitung kuadrat rerata dalam antar group

j. $\quad$ F hitung

k. Taraf signifikansi

1. F table

m. Tabel ringkasan anova

n. Kriteria pengujian jika $\mathrm{F}$ hitung $>=\mathrm{F}$ table, maka tolak Ho berarti signifikan.

o. Kesimpulan, Ho ditolak dan $\mathrm{H} 1$ diterima. Jadi, terdapat perbedaan yang signifikan.

\section{Analisis Data Kualitatif}

Analisis data kualitatif (Bogdan \& Biklen, dalam Moleong, 2009 : 248) adalah upaya yang dilakukan dengan jalan bekerja dengan jalan bekerja dengan data, mengorganisasikan data, memilah-milahnya menjadi satuan yang dapat dikelola, mensintesiskannya, mencari dan menemukan apa yang penting dan apa yang dipelajari, dan memutuskan apa yang dapat diceritakan kepada orang lain.

Analisis data pada penilitian ini secara deskriptif, yaitu data dikumpulkan berupa kata kata, gambar yang berasal dari hasil wawancara, catatan lapangan, foto, dokumen pribadi dan dokumen resmi lainnya.

\section{Hipotesis Penelitian}

Hipotesis dalam penelitian ini adalah :

Ho : Keuntungan (profit) produk organik sama dengan produk non-organik.

$\mathrm{Hi}$ : Keuntungan (profit) produk organik berbeda dengan produk non-organik.

\section{HASIL DAN PEMBAHASAN}

\section{Gambaran Umum Kondisi Daerah Kabupaten Malang}

\section{Keadaan Geografis}

Kabupaten Malang adalah sebuah Kabupaten di Provinsi Jawa Timur, Indonesia. Letak wilayahnya berada di daerah pegunungan antara 112'17'10,90"-122'57'00,00" Bujur Timur dan 7’44'55,11"80'26’35,45" Lintang Selatan. Berdasarkan Peraturan Pemerintah Nomor 18 Tahun 2008, Kota Kepanjen ditetapkan sebagai ibu kota Kabupaten Malang yang baru. Kota Kepanjen saat ini sedang berbenah diri agar nantinya layak sebagai ibu kota kabupaten. Kabupaten ini berbatasan langsung dengan Kabupaten Jombang, Kabupaten Mojokerto, Kota Batu, dan Kabupaten Pasuruan di utara, Kabupaten Lumajang di timur, Samudera Hindia di selatan, serta Kabupaten Blitar dan Kabupaten Kediri di barat. Sebagian besar wilayahnya merupakan pegunungan yang berhawa sejuk, Malang dikenal sebagai salah satu daerah tujuan wisata utama di Jawa Timur. 
Kabupaten Malang terdiri atas 33 kecamatan, yang dibagi lagi menjadi sejumlah desa dan kelurahan. Dengan komposisi jumlah penduduk 2,4 juta jiwa (BPS, 2006), kepadatan 804/km dan pertumbuhan 1,4\%. Pusat pemerintahan Kabupaten Malang berada di Kecamatan Kepanjen. Pusat pemerintahan sebelumnya berada di Kota Malang. Kota Batu dahulu bagian dari Kabupaten Malang, sejak tahun 2001 memisahkan diri setelah ditetapkan menjadi kota. Ibukota kecamatan yang cukup besar di Kabupaten Malang antara lain Lawang, Singosari, Dampit, dan Kepanjen.

Kabupaten Malang adalah kabupaten terluas kedua di Jawa Timur setelah Kabupaten Banyuwangi. Sebagian besar wilayahnya berupa pegunungan. Bagian barat dan barat laut berupa pegunungan, dengan puncaknya Gunung Arjuno (3.339 m) dan Gunung Kawi (2.651 m). Di pegunungan ini terdapat mata air Sungai Brantas, sungai terpanjang di Jawa Timur. Bagian timur merupakan kompleks Pegunungan Bromo-Tengger-Semeru, dengan puncaknya Gunung Bromo (2.392 m) dan Gunung Semeru $(3.676 \mathrm{~m}$ ). Gunung Semeru adalah gunung tertinggi di Pulau Jawa. Kota Malang sendiri berada di cekungan antara kedua wilayah pegunungan tersebut. Bagian selatan berupa pegunungan dan dataran bergelombang. Dataran rendah di pesisir selatan cukup sempit dan sebagian besar pantainya berbukit.

Kabupaten Malang memiliki potensi pertanian dengan iklim sejuk. Daerah utara dan timur banyak digunakan untuk perkebunan apel. Daerah pegunungan di barat banyak ditanami sayuran dan menjadi salah satu penghasil sayuran utama di Jawa Timur. Daerah selatan banyak digunakan ditanami tebu dan hortikultura, seperti salak dan semangka. Selain perkebunan teh, Kabupaten Malang juga berpotensi untuk perkebunanan kopi,dan cokelat (daerah pegunungan Kecamatan Tirtoyudo). Hutan jati banyak terdapat di bagian selatan yang merupakan daerah pegunungan kapur. Berdasarkan struktur tata ruang, Kabupaten Malang dapat dilihat pada gambar 2.

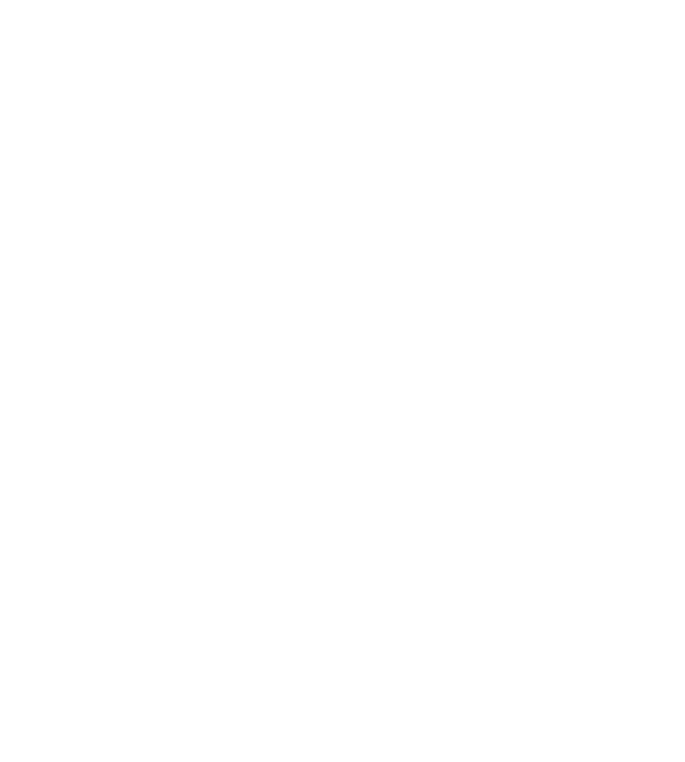

Gambar 2. Peta Struktur Ruang Wilayah Kabupaten Malang 


\section{Kondisi Perekonomian Daerah Kab. Malang}

Kabupaten Malang merupakan satu kabupaten yang tergolong memiliki tingkat aktivitas ekonomi yang cukup tinggi. Hal ini terlihat dari besarnya jumlah Produk Domestik Regional Bruto (PDRB) Kabupaten Malang yang menduduki peringkat 6 dari 33 kabupaten/kota yang ada di propinsi Jawa Timur setelah Kota Surabaya, Kota Kediri, Kabupaten Sidoarjo, Kabupaten Kediri dan Kabupaten Pasuruan. Cukup tingginya aktivitas ekonomi di Kabupaten Malang tidak terlepas dari tingginya aktivitas masyarakat dalam masing-masing sektor ekonomi yang ada di Kabupaten Malang. Sektor ekonomi yang memberikan kontribusi paling tinggi selama kurun waktu lima tahun terakhir adalah sektor pertanian, kemudian disusul oleh sektor perdagangan, hotel, dan restoran, sektor industri pengolahan serta sektor jasa. Apabila dikelompokan menjadi 3 sektor pokok, yaitu kelompok sektor primer, sekunder dan tertier. Sektor primer mencakup sektor pertanian, sektor pertambangan dan Galian. Peranan kelompok sektor primer lima tahun terakhir memberikan kontribusi sebesar 34,53\% tahun 2004, yang didominasi sektor pertanian. Hal ini dapat dilihat pada tabel 1 berikut:

Tabel 1. Kontribusi Masing-Masing Sektor Produk Domestik Regional Bruto (PDRB) Kabupaten Malang Tahun Atas Dasar Harga Konstan (2000-2004) ( \%)

\begin{tabular}{|r|l|r|r|r|r|r|r|}
\hline No & \multicolumn{1}{|c|}{ Sektor } & $\mathbf{2 0 0 0}$ & \multicolumn{1}{|c|}{$\mathbf{2 0 0 1}$} & \multicolumn{1}{|c|}{$\mathbf{2 0 0 2}$} & \multicolumn{1}{c|}{$\mathbf{2 0 0 3}$} & \multicolumn{1}{|c|}{$\mathbf{2 0 0 4}$} & \multicolumn{1}{c|}{ rerata } \\
\hline & Sektor Primer & $\mathbf{2 9 , 8 1}$ & $\mathbf{3 0 , 7 9}$ & $\mathbf{3 0 , 4 5}$ & $\mathbf{3 4 , 3 8}$ & $\mathbf{3 4 , 5 3}$ & $\mathbf{3 1 , 9 9}$ \\
\hline $\mathbf{1}$ & Pertanian & 29,15 & 30,09 & 29,74 & 31,97 & 32,05 & 30,60 \\
\hline $\mathbf{2}$ & Pertambangan & 0,66 & 0,69 & 0,71 & 2,42 & 2,48 & $\mathbf{1 , 3 9}$ \\
\hline & Sektor Sekunder & $\mathbf{1 7 , 9 1}$ & $\mathbf{1 8 , 5 3}$ & $\mathbf{1 8 , 5 8}$ & $\mathbf{1 9 , 0 8}$ & $\mathbf{1 9 , 6 5}$ & $\mathbf{1 8 , 7 5}$ \\
\hline $\mathbf{3}$ & Industri & 14,14 & 14,59 & 14,60 & 16,13 & 16,64 & 15,22 \\
\hline $\mathbf{4}$ & Listrik, Gas, Air Bersih & 2,12 & 2,32 & 2,36 & 1,54 & 1,56 & 1,98 \\
\hline $\mathbf{5}$ & Konstruksi & 1,64 & 1,63 & 1,61 & 1,40 & 1,45 & 1,55 \\
\hline & Sektor Tersier & $\mathbf{5 2 , 2 8}$ & $\mathbf{5 0 , 6 8}$ & $\mathbf{5 0 , 9 7}$ & $\mathbf{4 6 , 5 4}$ & $\mathbf{4 5 , 8 3}$ & $\mathbf{4 9 , 2 6}$ \\
\hline $\mathbf{6}$ & Perdagangan, Hotel \& Restoran & 23,65 & 22,55 & 22,95 & 23,43 & 23,36 & 23,19 \\
\hline $\mathbf{7}$ & Pengangkutan \& Komunikasi & 8,89 & 8,19 & 8,05 & 4,65 & 4,58 & 6,87 \\
\hline $\mathbf{8}$ & Keuangan, Persewaan \& Jasa & 4,92 & 5,34 & 5,44 & 3,94 & 3,87 & 4,70 \\
\hline $\mathbf{9}$ & Jasa-jasa & 14,82 & 14,59 & 14,53 & 14,52 & 14,01 & 14,50 \\
\hline & PDRB & $\mathbf{1 0 0 , 0 0}$ & $\mathbf{1 0 0 , 0 0}$ & $\mathbf{1 0 0 , 0 0}$ & $\mathbf{1 0 0 , 0 0}$ & $\mathbf{1 0 0 , 0 0}$ & 100,00 \\
\hline
\end{tabular}

Sumber: BPS, data diolah

\section{Kondisi Ekonomi Kecamatan Bantur Kab. Malang}

Penelitian ini secara mikro meninjau kondisi ekonomi Kecamatan Bantur Kabupaten Malang, karena di wilayah tersebut terdapat proyek percontohan sistem pertanian organik terpadu meliputi ternak, tanaman dan ikan. Dengan demikian kebijakan ekonomi secara jangka panjang perlu melihat potensi ekonomi di wilayah kecamatan tersebut dengan mengkaitkan pengembangan wilayah kabupaten Malang. Hal ini dengan meninjau kondisi spatial geografis kecamatan Bantur di lingkup kabupaten Malang sebagai daerah yang potensi pariwisata pantai yaitu Bale Kambang. Tentunya di tupang potensi ekonomi basis di kecamatan Bantur. Secara perwilayahan di kabupaten lokasi kecamatan Bantur dapat di tunjukkan pada gambar 3 berikut: 


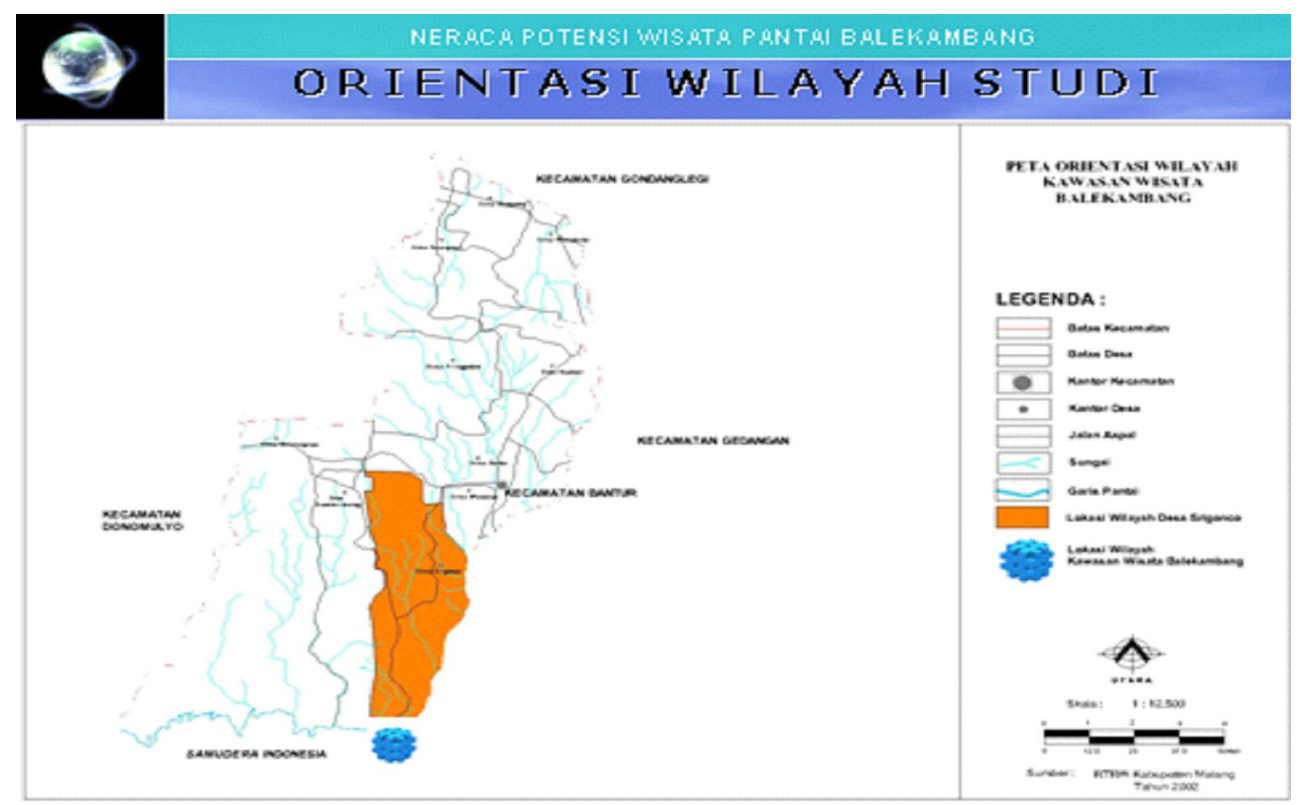

Gambar 3. Peta Wilayah Studi terkait potensi wisata Pantai Balekambang

\section{Analisis Sektor Basis Kabupaten Malang}

Analisis LQ ini digunakan untuk mengidentifikasi kekuatan/ kelemahan wilayah dibandingkan secara relatif dengan wilayah yang lebih luas. Untuk Kabupaten Malang mempunyai potensi relatif tinggi di banding Kabupaten lain di Jawa Timur, jika koefisien LQ > 1. Potensi yang positif tersebut digunakan dalam strategi pengembangan wilayah. Selain itu, LQ juga digunakan sebagai petunjuk adanya keunggulan komparatif yang dapat digunakan bagi sektor-sektor yang telah lama berkembang, serta melihat secara langsung apakah komoditi itu memiliki prospek ekspor, dalam arti mempunyai kuantita yang lebih dari cukup untuk memenuhi kebutuhan/konsumsi di wilayah Kabupaten Malang, atau dapat dikatakan surplus, sehingga kelebihan tersebut dapat di bawa ke daerah lain. Tapi perlu diingat analisis ini merupakan indikasi, sehingga untuk tindakan operasional perlu dilakukan analisis yang lebih detil. Gambaran LQ Kabupaten Malang pada 1993-2002 digunakan untuk menentukan kebijakan pada tataran awal dapat dilihat pada tabel 2. berikut : 
Relasi Konstitusi dengan Usaha Tani Ikan, Sayur, Telur Organik dan Non-Organik ...

Tabel 2. Analisis LQ Kabupaten Malang Tahun 1993-2002

\begin{tabular}{|c|c|c|c|c|c|c|c|c|c|c|c|}
\hline No & Sektor & 1993 & 1994 & 1995 & 1996 & 1997 & 1998 & 1999 & 2000 & 2001 & 2002 \\
\hline 1 & Pertanian & 2,18 & 1,68 & 1,77 & 1,78 & 1,78 & 1,71 & 1,71 & 1,64 & 1,56 & 1,57 \\
\hline 2 & Pertambangan & 0,42 & 0,34 & 0,37 & 0,41 & 0,44 & 0,75 & 0,45 & 0,30 & 0,34 & 0,35 \\
\hline 3 & Industri & 0,42 & 0,50 & 0,48 & 0,48 & 0,51 & 0,51 & 0,51 & 0,52 & 0,45 & 0,52 \\
\hline 4 & Listrik, Gas, Air Bersih & 1,02 & 0,96 & 0,91 & 0,78 & 0,90 & 0,87 & 0,78 & 0,00 & 1,48 & 1,41 \\
\hline 5 & Konstruksi & 0,23 & 0,28 & 0,28 & 0,28 & 0,33 & 0,32 & 0,35 & 0,36 & 0,42 & 0,42 \\
\hline 6 & Perdagangan, Hotel \& Restoran & 1,27 & 1,18 & 1,17 & 1,19 & 1,09 & 1,08 & 1,09 & 1,14 & 0,89 & 0,87 \\
\hline 7 & Pengangkutan \& Komunikasi & 0,66 & 1,14 & 1,14 & 1,15 & 1,28 & 1,14 & 1,07 & 1,08 & 1,59 & 1,44 \\
\hline 8 & Keuangan, Persewaan \& Jasa & 1,44 & 0,85 & 0,86 & 0,89 & 0,96 & 0,81 & 0,82 & 0,90 & 1,14 & 1,14 \\
\hline 9 & Jasa-jasa & 0,22 & 1,28 & 1,34 & 1,40 & 1,41 & 1,31 & 1,31 & 1,33 & 1,70 & 1,69 \\
\hline
\end{tabular}

Sumber: Hasil analisis, BPS data diolah

Berdasarkan hasil perhitungan diatas menunjukkan bahwa setidaknya ada tiga sektor yang menjadi basis kegiatan ekonomi di Kabupaten Malang selama empat tahun terakhir, yaitu: sektor pertanian, sektor pertambangan, dan sektor jasa-jasa. Jika dilihat dari nilai LQ yang ada, maka sektor-sektor tersebut mempunyai kemampuan yang lebih besar dibandingkan dengan Propinsi Jawa Timur secara keseluruhan. Hal ini menandakan bahwa kegiatan dalam sektor ekonomi tersebut mempunyai potensi untuk dikembangkan. Alasan sektor tersebut berpotensi untuk dikembangkan adalah karena sektor tersebut mengalami surplus sehingga dapat melakukan ekspor dan memiliki keuntungan lokasi pada daerah tersebut.

\section{Analisis Basis Ekonomi Kecamatan Bantur}

Di Kecamatan Bantur produksi tanaman pangan meliputi padi, jagung, ubi kayu, kacang tanah dan kedele menunjukkan kondisi basis karena koefisien LQ > 1. Berarti sektor pertanian ladang potensi untuk dikembangkan. Untuk melengkapi analisis produksi tanaman pangan perlu memperhatikan luas panennya. Apabila luas panen juga menunjukan angka koefisien LQ > 1 . Hal ini dapat diidentifikasi bahwa sub sektor tanaman pangan tersebut dapat memberikan sumbangan terhadap ekonomi wilayah di Kecamatan Bantur. Pada tahun 2008 Kecamatan Bantur luas panen tanaman jagung relatif kecil di bandingkan dengan kecamatan lain di kabupaten Malang, namun produksi jagung relatif tinggi di banding kecamatan lainnya. Hal ini ditengarahi adanya perlakuan khusus pada tanaman jagung yaitu adanya intensifikasi. Secara detil perlu diteliti lebih mendalam. Mengenai data dapat di tunjukkan pada tabel 3 dan 4 berikut :

Tabel 3. LQ Produksi (Padi, Jagung, Ubi Kayu, Kacang Tanah, Kedele) Ladang di Kecamatan Bantur Kabupaten Malang Tahun 2008

\begin{tabular}{clrrc}
\hline No. & PRODUKSI ( TON ) & KAB. MALANG & KEC. BANTUR & \multicolumn{1}{c}{ LQ } \\
\hline $\mathbf{1}$ & Padi & 28729 & 2294 & 9.2697 \\
$\mathbf{2}$ & Jagung & 215459 & 10947 & 5.8982 \\
$\mathbf{3}$ & Ubi Kayu & 700039 & 76276 & 1.2649 \\
$\mathbf{4}$ & Kacang Tanah & 7540 & 726 & 1.1177 \\
$\mathbf{5}$ & Kedele & 898 & 177 & 2.2881 \\
& & $\mathbf{9 5 2 6 6 5}$ & $\mathbf{9 0 4 2 0}$ & \\
\hline
\end{tabular}

Sumber: Data Sekunder Diolah 
Tabel 4. LQ Luas Panen (Padi, Jagung, Ubi Kayu, Kacang Tanah, Kedele) Ladang di Kecamatan Bantur Kabupaten Malang Tahun 2008

\begin{tabular}{clrrc}
\hline No. & LUAS PANEN ( Ha ) & KAB. MALANG & KEC. BANTUR & LQ \\
\hline $\mathbf{1}$ & Padi & 6028 & 500 & 1.096496 \\
$\mathbf{2}$ & Jagung & 48447 & 2666 & 0.727450 \\
$\mathbf{3}$ & Ubi Kayu & 18670 & 2188 & 1.549220 \\
$\mathbf{4}$ & Kacang Tanah & 3494 & 347 & 1.312855 \\
$\mathbf{5}$ & Kedele & 800 & 157 & 2.594299 \\
& & $\mathbf{7 7 4 3 9}$ & $\mathbf{5 8 5 8}$ & \\
\hline
\end{tabular}

Sumber: Data Sekunder Diolah

Untuk populasi ternak unggas di kecamatan Bantur sebagai basis ekonomi adalah ayam pedaging dan itik. Berarti unggas tersebut menunjuk surplus, sehingga dapat dikirim keluar kecamatan Bantur, karena sudah mencukupi untuk dikonsumsi sendiri. Hal ini dapat meningkatkan ekonomi wilayah kcamatan Bantur. Nilai LQ $>1$ untuk ternak unggas ayam pedaging dan itik di kecamatan Bantur tersebut adalah relatif di banding kecamatan lain di kabupaten Malang. Data tersebut dapat dilihat pada tabel .5

Tabel.5. LQ Populasi Ternak Unggas di Kecamatan Kab. Malang Tahun 2008

\begin{tabular}{llrrr}
\hline No. & $\begin{array}{l}\text { POPULASI TERNAK UNGGAS } \\
\text { (EKOR) }\end{array}$ & KAB. MALANG & KEC. BANTUR & LQ \\
\hline $\mathbf{1}$ & Ayam Buras & 1934532 & 34764 & 0.80107 \\
$\mathbf{2}$ & Ayam Petelur & 2132408 & 26026 & 0.54407 \\
$\mathbf{3}$ & Ayam Pedaging & 10797500 & 271750 & 1.12192 \\
$\mathbf{4}$ & Itik & 115765 & 3760 & 1.44787 \\
$\mathbf{5}$ & Entog $\quad$ JUMLAH & 38340 & 606 & 0.70459 \\
& & $\mathbf{1 5 0 1 8 5 4 5}$ & $\mathbf{3 3 6 9 0 6}$ & \\
\hline
\end{tabular}

Sumber: Data Sekunder Diolah

Mengenai budidaya perikanan di Kecamatan Bantur yang menunjukkan LQ > lebih satu (1), berarti terdapat kelebihan untuk dikonsumsi daerah itu sendiri, sehingga di ekspor atau di kirim ke luar daerah, yaitu budidaya perikanan kolam, sungai dan laut. Adapun datanya dapat ditunjukkan pada tabel 6 .

Tabel.6. LQ Produksi Budidaya Perikanan Di Kecamatan Bantur Kabupaten Malang Tahun 2008

\begin{tabular}{llrrr}
\hline No. & PRODUKSI PERIKANAN ( TON ) & KAB. MALANG & KEC. BANTUR & \multicolumn{1}{c}{ LQ } \\
\hline $\mathbf{1}$ & Kolam & 108.67 & 0.79 & 1.1775 \\
$\mathbf{2}$ & Tambak & 443.65 & 0 & 0 \\
$\mathbf{3}$ & Sungai & 19.18 & 1.2 & 10.1341 \\
$\mathbf{4}$ & Waduk & 190.7 & 0 & 0 \\
$\mathbf{5}$ & Laut & 9223.7 & 59.66 & 1.04769 \\
& & $\mathbf{9 9 8 5 . 9}$ & $\mathbf{6 1 . 6 5}$ & \\
\hline
\end{tabular}

Sumber: Data Sekunder Diolah

Matapencaharian penduduk di kecamatan Bantur yang merupakan basis adalah pada sektor pertanian yang paling utama. Kemudian sektor yang relatif lebih tinggi dibanding kecamatan lainnya di kabupaten Malang adalah pertambangan, industri pengolahan, konstruksi, jasa dan 
lainnya. Dengan demikian sektor pertanian dapat menopang matapencaharian penduduk di kecamatan Bantur. Untuk kedepan sektor pertanian tersebut tetap dipertahankan. Data secara jelas dapat dilihat pada tabel 6 .

Tabel 7. Penduduk Menurut Matapencaharian Di Kecamatan Bantur Kabupaten Malang Tahun 2008

\begin{tabular}{llrrr}
\hline $\mathbf{N 0}$ & MATAPENCAHARIAN PENDUDUK & \multicolumn{2}{l}{ KAB. } \\
MALANG & KEC. BANTUR & LQ \\
\hline $\mathbf{1}$ & Pertanian & 7716 & 9390 & 40.6612 \\
$\mathbf{2}$ & Pertambangan & 4040 & 121 & 1.00071 \\
$\mathbf{3}$ & Industri Pengolahan & 98862 & 2959 & 1.00005 \\
$\mathbf{4}$ & Listrik, Gas dan Air & 1455 & 43 & 0.98744 \\
$\mathbf{5}$ & Konstruksi & 84432 & 2527 & 1.00001 \\
$\mathbf{6}$ & Perdagangan & 143852 & 4305 & 0.99991 \\
$\mathbf{7}$ & Aangkutan/ Komunikasi & 51233 & 1533 & 0.99976 \\
$\mathbf{8}$ & Jasa & 87853 & 2630 & 1.00024 \\
$\mathbf{9}$ & Lainnya & 74905 & 2242 & 1.00007 \\
& & $\mathbf{8 6 0 3 6 9}$ & $\mathbf{2 5 7 5 0}$ & \\
\hline
\end{tabular}

Sumber: Data Sekunder Diolah

\section{Hasil Wawancara}

Penelitian yang disampaikan pada penjelasan sebelumnya telah dilakukan pada tahun 2007. Kemudian pada tahun 2010 dilakukan penelitian yang dilakukan secara kualitatif dan kuantitatif. Sedang penelitian kualitatif dengan metode wawancara kepada informan utama( key person), yaitu orang yang dianggap paling tahu sebagai pelaksana di lapang. Informan tersebut adalah bapak Sulis dan istri serta saudaranya yang tinggal di Desa Wonokerto Kecamatan Bantur Kabupaten Malang. Letak rumah pak Sulis berada satu lokasi dengan Koperasi Mentas yang dapat ditunjukkan pada foto berikut :
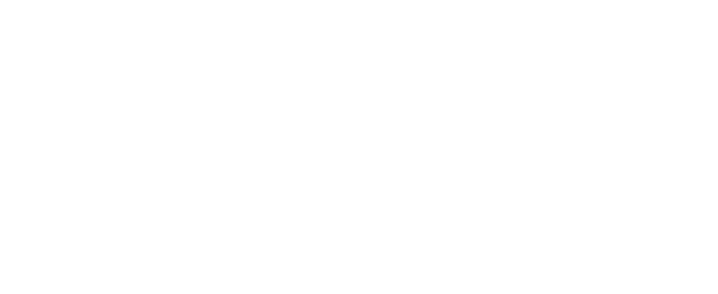

Gambar 4. Objek Penelitian Ternak Sapi dan Koperasi Pertanian MENTAS

Hasil wawancara dengan keluarga bapak Sulis mengenai usaha ternak, tanaman, ikan secara organik yang telah dilakukan selama ini adalah sebagai berikut:

Pembuatan biogas membutuhkan dana sebanyak Rp 700.000,00 volume per $\mathrm{m}^{3}$. Untuk satu rumah tangga minimal membutuhkan $8 \mathrm{~m}^{3}$. Dengan demikian dana yang dikeluarkan sekitar $8 \mathrm{X}$ Rp 700.000,00 = Rp 5.400.000,00. Sedangkan umur investasi selama 5 tahun. Memang pada awalnya dana yang dibutuhkan relatif besar, namun untuk selanjutnya tinggal menggunakan biogasnya selama bertahun-tahun. Hal ini telah dipraktekkan selama 16 tahun, yaitu mulai tahun 
1994. Biogas ini selain untuk kompor juga untuk substitusi listrik, jika terjadi mati listrik di rumah. Hasil sisa(limbah) dari proses biogas dijadikan kompos/pupuk dapat dijual per zak ( 20 - 25 kg) seharga Rp 20.000,00.

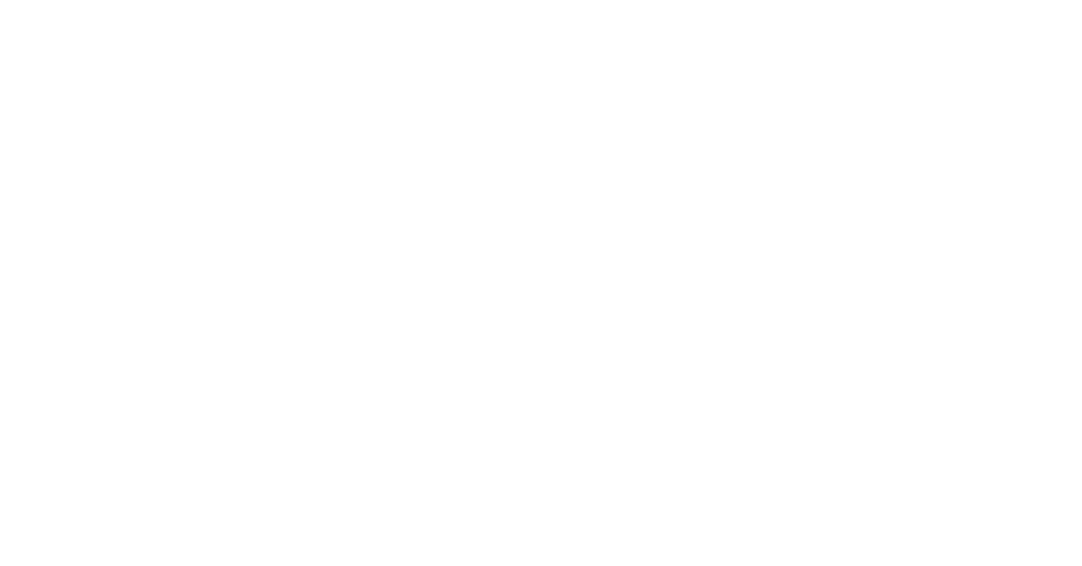

Gambar 5. Proses Pembuatan Biogas dari Kotoran Sapi

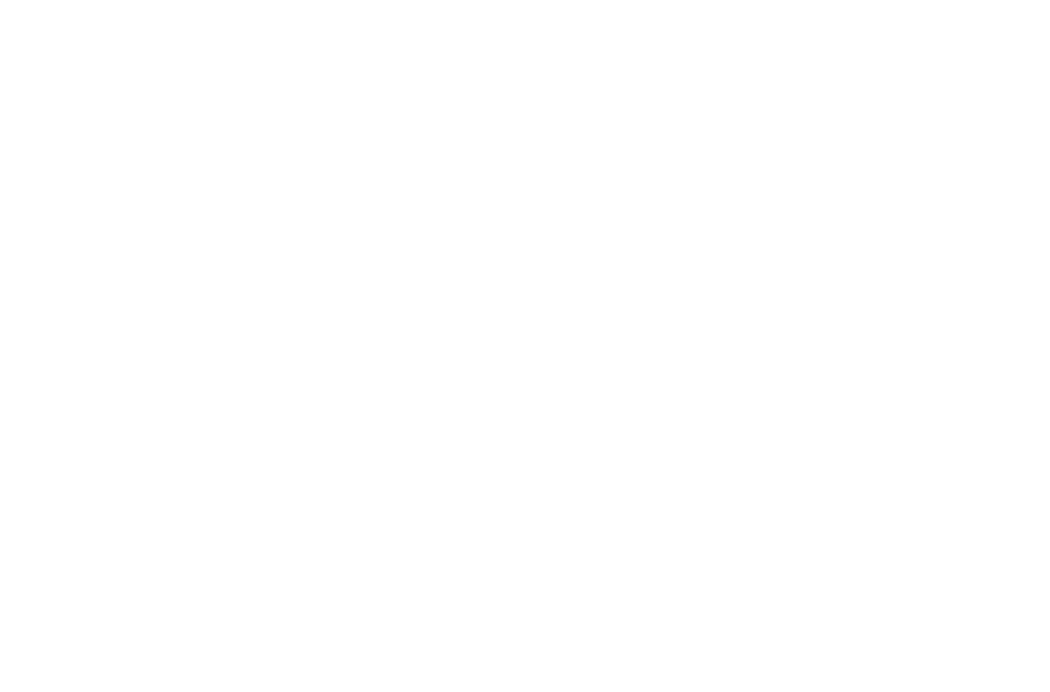

Gambar 6. Proses Ternak Ikan Lobster

Ternak sapi perah yang kotorannya merupakan bahan baku dari biogas. Selain itu sapi itu sendiri juga dijadikan usaha untuk dijual anaknya dan susunya. Sapi berumur 2 tahun susunya sudah produksi se hari sebanyak 10 liter dengan harga per liter Rp 3.200,00. Sedang harga jual sapi usia 2 tahun sekitar Rp 13.000.000,00. Adapun kebutuhan pakannya satu hari dengan komposisi rumput gajah, konsentrat, ampas tahu dan singkong biaya sebesar Rp 12.500,00 untuk satu ekor sapi. 
Untuk ternak kelinci, modal pertama dua ekor dengan dana Rp 200.000,00. Dua bulan kemudian telah dapat menghasilkan anak sebanyak 7 sampai 10 ekor. Sedangkan pada umur empat puluh(40) hari sudah dapat dijual dengan harga Rp 20.000,00. Adapun kebutuhan pakan satu hari terdiri dari rumput, ampas tahu, konsentrat dan obat-obatan (kunir dan temulawak) dengan biaya sekitar Rp 1.000,00 per ekor kelinci.
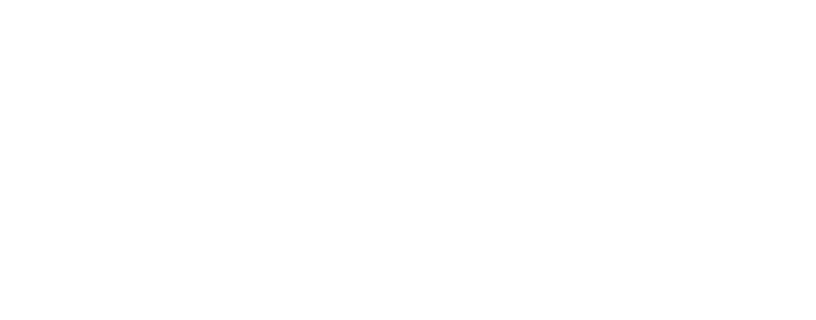

Gambar 7. Ternak Kelinci dan Ayam Kampung

Sementara itu, ternak Ayam (kampung) butuh modal enam ekor ayam betina (babon) harga $\mathrm{Rp} 50.000,00$ per ekor dan satu ayam jago harga $\mathrm{Rp} 75.000,00$ - Rp 100.000,00. Jadi total dana awal yang dibutuhkan sekitar Rp 400.000,00. Selang sepuluh hari telah menghasilkan telor sebanyak sepuluh butir per ekor ayam babon. Hari telur per butir Rp 1000,00. Sedangkan pakannya tidak diadakan secara khusus karena ayam-ayam tersebut dibiarkan berkeliaran mencari pakan sendiri.

Sayuran untuk diambil bibitnya terdiri dari sawi, bayam, kangkung, kacang panjang dan kacang hijau. Sarana produksi terdiri dari pupuk organik, obat-obatan (mimbo dan pahitan). Kegiatan ini telah dimulai sejak tahun 2007 atas pembinaan dari Tim UB dari Program Difusi IPTEK. Ternyata untuk penanaman bibit kangkung tidak membuahkan hasil yang diharapkan atau dapat dikatakan gagal.

\section{Hasil Usaha Tani}

Hasil usaha tani dalam penelitian ini analisisnya menggunakan metode delphi, yaitu berdasarkan pendapat para ahli yang kompeten dibidang budidaya pertanian (sayuran,ternak,ikan). Kemudian dilengkapi dengan penampilan data yang mendukung analisis usaha tani tersebut. Hal ini akan diuraikan sebagai berikut:

\section{Usaha Ternak Ayam Arab}

Usaha ternak ayam arab ini yang diambil adalah telurnya. Berdasarkan hasil penelitian para ahli dapat disimpulkan perbandingan kajian ekonomi antara hasil telur ayam arab diperlakukan dengan sistem organik (dengan sludge) dengan sistem kimia sintetis. Hasilnya di tunjukkan pada tabel 7. berikut: 
Tabel.7. Perbandingan Harga Telur Organik dan Anorganik(kimia sintetis)

\begin{tabular}{llll}
\hline No & \multicolumn{1}{c}{ Keterangan } & \multicolumn{1}{c}{ Organik } & \multicolumn{1}{c}{ Anorganik } \\
\hline 1. & Harga Telur ( on farm) & $\mathrm{Rp} \mathrm{800,-/butir}$ & $\mathrm{Rp} \mathrm{650,-/butir}$ \\
2. & Harga Pakan & $\mathrm{Rp} \mathrm{2.451,-/kg}$ & $\mathrm{Rp} \mathrm{2.505,-/kg}$ \\
3. & Biaya pakan/1000 ekor/hr(a $80 \mathrm{~g})$ (Total Cost) & $\mathrm{Rp} \mathrm{196.080,-}$ & $\mathrm{Rp} \mathrm{200.400,-}$ \\
4. & Penjualan telur jika produksinya 65\%( asumsi & $\mathrm{Rp} \mathrm{520.000,-}$ & $\mathrm{Rp} \mathrm{422.500,-}$ \\
& pemeliharaan 1000 ekor)(Total Revenue) & & \\
5. & Profit (TR - TC) (Income) & $\mathrm{Rp} \mathrm{323.920,-}$ & $\mathrm{Rp} \mathrm{222.100,-}$ \\
$\mathbf{6}$ & $\begin{array}{l}\text { Perbedaan Income (organik - anorganik = Rp } \\
\text { 101.820,-) }\end{array}$ & & \\
\hline
\end{tabular}

Sumber: Agustina 2007:84

\section{Usaha Tanaman Sayuran}

Usaha tanaman sayuran dicontohkan tanaman sawi yang diambil bijinya untuk bibit. Adapun perlakuan sistem tanam dengan bahan organik, yaitu diberi slugde cair dan paitan. Lokasi uji coba di kawasan wilayah Kecamatan Bantur Kabupaten Malang yang dilakukan para ahli dari Universitas Brawijaya (UB) RISTEK. Kemudian pemasarannya dengan label Koperasi Mentas UNIBRAW RISTEK. Secara ringkas analisis kelayakan usaha produksi benih sawi dapat dipaparkan sebagai berikut:

Penerimaan hasil penjualan benih sawi Tim UB - Ristek (2007) dengan pupuk organik selama periode 4 bulan:

Produksi benih sawi kering $\quad=80 \%$ X 30.000 tanaman X 20,89 g/tanaman $=501.360 \mathrm{~kg} / \mathrm{ha}$ Pengemasan @ 50 g/pak, harga benih Rp 10.000,00 per 50 g atau Rp 200.000,00 per kg.

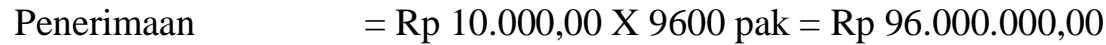

Keuntungan Kotor $=\operatorname{Rp} 96.000 .000,00-\operatorname{Rp} 34.800 .000,00=\operatorname{Rp} 60.700 .000,00$

Bunga Bank $\quad=1,5 \%$ X 4 bulan X Rp 60.700.000,00 = Rp 3.642.000,00

Keuntungan bersih $=\operatorname{Rp~60.700.000,00~-~Rp~3.642.000,00~=~Rp~57.085.000,00~}$

Kelayakan Usaha

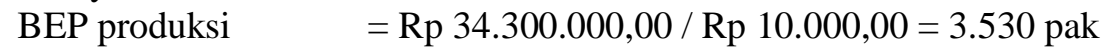

$\mathrm{B} / \mathrm{C} \quad=\operatorname{Rp} 96.000 .000,00 / \mathrm{Rp} 57.085 .000,00=2,68$

Penerimaan hasil penjualan benih sawi dengan penggunaan pupuk kimia sintetis (Sumpena,2005) selama periode 4 bulan:

Produksi benih sawi kering $\quad=80 \%$ X 30.000 tanaman X $20 \mathrm{~g} / \operatorname{tanaman}=480 \mathrm{~kg} / \mathrm{ha}$ Pengemasan@ 50 g/pak, harga benih Rp 7.500,00 per $50 \mathrm{~g}$ atau Rp 150.000,00 per kg.

Penerimaan $\quad=\operatorname{Rp~7.500,00~X~} 9600$ pak $=$ Rp 72.000.000,00

Keuntungan Kotor $=\operatorname{Rp} 72.000 .000,00-\operatorname{Rp} 28.104 .000,00=\operatorname{Rp} 43.896 .000,00$

Bunga Bank $\quad=1,5 \%$ X 4 bulan X Rp 60.700.000,00 = Rp 3.642.000,00

Keuntungan bersih $=\operatorname{Rp} 43.896 .000,00-\operatorname{Rp} 2.633 .760,00=\operatorname{Rp} 41.262 .240,00$

Kelayakan Usaha

BEP produksi $\quad=\mathrm{Rp} 28.104 .000,00 / \mathrm{Rp} 7.500,00=3.747,2 \mathrm{pak}$

$\mathrm{B} / \mathrm{C}=\mathrm{Rp} 72.000 .000,00 / \mathrm{Rp} 28.104 .000,00=2,562$ 


\section{Analisis Usaha Ikan}

Usaha ikan yang terdiri dari ikan lele, nila dan lobster dengan cara budidaya dengan sistem organik dengan pakan sludge dan non-organik (komersial) yang di uji coba pada luasan $24 \mathrm{~m}^{2}$ dalam satu siklus usaha. Mengenai hasil secara ringkas dapat ditunjukkan pada tabel 8 berikut:

Tabel. 8. Analisis Usaha Ikan secara Komersial (non-Organik) \& Sludge (Organik)

\begin{tabular}{l|r|r|r|r|r|r}
\hline & \multicolumn{2}{|c|}{ Lele } & \multicolumn{2}{c|}{ Nila } & \multicolumn{2}{c}{ Lobster } \\
\cline { 2 - 7 } Keterangan & Komersial & Sludge & Komersial & Sludge & Komersial & Sludge \\
\hline Jumlah benih (ekor) & 2000 & 2000 & 2000 & 2000 & 500 & 500 \\
Ukuran panen Ekor/Kg & 9 & 10 & 10 & 10 & 10 & 15 \\
Jumlah panen (ekor) & 1400 & 1300 & 1300 & 1300 & 250 & 250 \\
Biomass (kg) & 155,6 & 130,0 & 130,0 & 130,0 & 25,0 & 16,7 \\
JumlahPakan (kg) & 187 & 221 & 156 & 221 & 37 & 33 \\
Harga benih (Rp) & 200000 & 200000 & 200000 & 200000 & 500000 & 500000 \\
Harga-Ikan & 1244444 & 1040000 & 1040000 & 1040000 & 375700 & 1666666 \\
Harga Pakan (Rp/Kg) & 840000 & 442000 & 702000 & 375700 & 3000000 & 83333 \\
Pengeluaran (Rp) & 1040000 & 642000 & 902000 & 575700 & 3500000 & 583333 \\
Penerimaan (Rp) & 12444444 & 1040000 & 1040000 & 1040000 & 3750000 & 1666667 \\
Untung/Rugi (Rp) & 204444 & 398000 & 138000 & 464300 & 250000 & 1083333 \\
\hline
\end{tabular}

Sumber: Data IPTEK

\section{Hasil Analisis ANOVA}

Analisis ANOVA merupakan analisis Uji Beda, yaitu melihat perbandingan antara keuntungan bersih ikan, sayur dan telur (ternak). Adapun data yang akan diuji dapat ditunjukkan pada tabel 9 berikut:

Tabel 9. Perbandingan Keuntungan Bersih(Profit) Ikan, Sayur dan Telur Organik dan Non-organik

\begin{tabular}{|c|c|c|c|}
\hline No. & Komoditi & Organik (Rp) & Non-Organik (Rp) \\
\hline 1. & Lele & 398.000 & 204.444 \\
\hline 2. & Nila & 464.300 & 138.000 \\
\hline 3. & Lobster & 1.083 .333 & 250.000 \\
\hline 4. & Benih Sawi & 57.085 .000 & 41.262 .240 \\
\hline 5. & Telur & 323.920 & 222.100 \\
\hline
\end{tabular}

Sumber: Hasil Penelitian Difusi IPTEK

Kemudian data tersebut dianalisis dengan dua metode yaitu:

- Metode I,rata-rata profit dengan varian masing-masing tidak sama.

- Metode II, rata-rata profit dengan varian diasumsikan sama.

Hasil perhitungan analisis dapat ditunjukkan pada tabel 10. berikut :

Tabel 10. ANOVA

\begin{tabular}{lccccc}
\hline & Sum of Squares & df & Mean Square & F & Sig. \\
\hline Between Groups & $2,99 \mathrm{E}+13$ & 1 & $2,9852 \mathrm{E}+13$ &, 061 &, 811 \\
Within Groups & $3,90 \mathrm{E}+15$ & 8 & $4,8805 \mathrm{E}+14$ & & \\
Total & $3,93 \mathrm{E}+15$ & 9 & & & \\
\hline
\end{tabular}

Sumber: Hasil perhitungan; $\alpha=5 \%$ 
Hasil analisis menunjukkan signifikan, dengan Ho diterima dan H1 ditolak. Berarti bahwa tidak terdapat perbedaan profit antara usaha tani organik dan non organik. Hal ini berlaku untuk usaha tani ikan lele, nila dan lobster. Demikian pula untuk usaha tani sayur sawi yang diambil benihnya, dan juga untuk telur. Dengan demikian hasil penelitian ini tidak sesuai dengan hipotesa yang dikemukakan. Makna dari hasil penelitian ini adalah sebatas obyek penelitian yang telah di uji, yaitu untuk usaha tani ikan dengan jenis lele, nila dan lobster.

Sedangkan tanaman sayur yang telah diuji adalah sawi, kemudian diambil bijinya untuk dijadikan benih, dengan tujuan sebagai suplai sayur sawi organik. Adapun usaha ternak ayam yang di uji adalah telurnya. Mengingat penelitian ini mempunyai keterbatasan waktu dan dana. Sehingga hanya mengikuti penelitian yang telah dilakukan sebelumnya. Kemudian diliakukan analisis statistik yaitu analisis varian yang disebut ANOVA, dengan tujuan membandingkan lebih dari dua rata-rata. Mengenai gunanya untuk menguji kemampuan generalisasi. Maksudnya dari signifikasi hasil penelitian anova satu jalur. Jika terbukti berbeda, berarti kedua sampel tersebut dapat digeneralisasikan, artinya data sampel dapat mewakili populasi. Apabila tidak menunjukkan perbedaan maka hasilnya adalah sebaliknya, yaitu tidak dapat digeneralisasikan. Kondisi ini bisa jadi disebabkan adanya keterbatasan jumlah sampel yang diuji.

Berdasarkan hasil uji beda (ANOVA), menunjukkan perbedaan dengan hasil perhitungan keuntungan bersih( profit) usaha tani secara manual. Secara statistik tidak menunjukkan perbedaan profit antara usaha tani organik dan non-organik. Sedangkan secara manual menunjukkan perbedaan profit antara usaha tani organik dan non-organik. Hal ini tentunya hanya berlaku untuk produk yang diteliti yaitu ikan(lele,nila,lobster), sayur sawi dan telur ayam. Berarti perbedaan profit tersebut adalah secara kebetulan atau sample dari penelitian ini ditambah jumlahnya. Mengingat keterbatasan dana dan waktu, maka penelitian ini dapat dilanjutkan lagi. Namun untuk sementara indikasi tidak ada perbedaan profit tersebut memberi peluang untuk disampaikan kepada produsen yang berminat usaha, yaitu lebih baik usaha produk organik yang aman buat lingkungan dan kesehatan.

Dengan demikian hasil penelitian ini diharapkan memberikan dampak positif terhadap prospek usaha tani organik di masa depan, khususnya untuk produk yang telah diteliti sebagai sample (obyek), meliputi tanaman sayur sawi , ikan (lele, nila, lobster), dan telur ayam. Dengan demikian usaha tani organik produk tersebut dapat dikembangkan secara luas dan kelola dengan manajemen yang baik. Hal ini tentu perlu campur tangan pemerintah sebagai lembaga yang ikut bertanggung jawab untuk meningkatkan ekonomi masyarakat dan wilayah. Dalam hal ini dapat diwakili Bappeda selaku lembaga perencana daerah. Jika bersentuhan dengan pemberdayaan masyarakat dan perdagangan, maka dapat dikelola oleh Dinas Perindustrian, Perdagangan \& Koperasi. Selain itu diperlukan Dinas Pertanian dan jajarannya yang terkait sebagai lembaga yang dapat mensertifikasi produk pertanian organik. Dengan demikian perlu ditangani secara holistic dan integrated. Sehingga dapat dilakukan beberapa langkah berikut ini:

1) Berdasarkan hasil identifikasi baik di Kecamatan Bantur dan Kabupaten Malang, sektor pertanian merupakan sektor basis ekonomi. Apalagi permintaan pasar luar negri terhadap produk organik cukup tinggi di banding pasar dalam negri. Mengingat tidak mudah untuk menembus pasar luar negri karena petani sering terbentur dengan sertifikasi organik yang 
diterima di tingkat internasional. Hal ini menjadi tantangan pemerintah dan swasta yang dapat membantu para produsen organik dalam mencarikan akses.

2) Membuat paguyuban para petani organik, tentunya di bantu oleh pemerintah. Untuk sementara masih bersifat swadaya masyarakat dan swasta yang bergerak sendiri-sendiri dan belum terkoordinir secara nyata.

3) Membuat jejaring diantara paguyuban produk organik, dalam rangka penguatan pasar baik lokal, regional, nasional maupun internasional. Selain itu perlu melakukan sosialisasi kepada masyarakat (konsumen dan produsen) tentang usaha tani organik dan manfaatnya secara ekonomi maupun lingkugan.

4) Melakukan diseminasi hasil-hasil penelitian keberba- gai kalangan akademisi, birokrat dan masyarakat umum.

5) Go organic segala bidang untuk mendukung pembangunan berwawasan lingkungan yang berkelanjutan.

\section{E. KESIMPULAN DAN REKOMENDASI}

\section{Kesimpulan}

Dari pembahasan dan analisis yang dilakukan didapatkan beberapa kesimpulan penelitian ini yakni:

1. Sektor pertanian merupakan sektor basis baik di Kecamatan Bantur maupun Kabupaten Malang. Hal ini nampak dari hasil identifikasi analisis LQ yang menunjukkan koefisien lebih dari satu, berarti sektor tersebut mampu memenuhi kebutuhan daerah/wilayahnya sendiri. Di Kecamatan Bantur potensi untuk tanaman pangan terdiri dari padi, jagung, ubi kayu, kacang tanah dan kedele. Khusus untuk tanaman jagung menunjukkan intensifikasi lahan. Hal ini nampak dari hasil analisis LQ luas tanam kurang dari satu , namun produksinya lebih dari satu. Sedang untuk ternak unggas adalah ayam pedaging dan itik. Kemudian untuk perikanan yang potensi adalah perikanan kolam, sungai dan laut.

2. Untuk lapangan pekerjaan yang mendominasi juga sektor pertanian, karena mata pencaharian penduduk mayoritas di pertanian

3. Kontribusi sektor primer paling besar diantara sektor sekunder dan tersier di Kabupaten Malang.

4. Hasil analisis ANOVA menunjukkan tidak ada perbedaan profit antara usaha tani ikan (lele, nila, lobster), sayuran sawi dan telur secara organik dan non-organik. Namun perhitungan usaha tani secara manual organik profitnya lebih tinggi di banding non-organik.

5. Sistem integrasi/terpadu antara usaha tani ternak, ikan dan sayur lebih efisien dan bersifat produksi bersih (zero waste); karena di dalam sistem tersebut terjadi proses yang terkait satu sama lain. Yaitu hasil (limbah) bio gas dari kotoran sapi berupa sludge dapat dijadikan kompos untuk pupuk tanaman dan tambahan pakan ayam maupun ikan. Sedangkan sayuran yang tidak terpakai dapat menunjang pakan sapi dan kelinci.

6. Prospek produk organik cukup menjanjikan terutama untuk pasar luar negeri. Sedangkan di dalam negeri juga mempunyai harapan untuk kota-kota besar. Dengan demikian masih merupakan tantangan di masa kini maupun ke depan. 


\section{Rekomendasi}

Berkaitan dengan hasil temuan dan kesimpulan dari penelitian ini maka disampaikan beberapa rekomendasi dari hasil penelitian ini yaitu:

1. Setelah diidentifikasi potensi yang terdapat di kecamatan Bantur dan kabupaten Malang, perlu dipetakan untuk menentukan alokasi spatial (perwilayahan). Sehingga dapat direkomendasikan untuk menentukan strategi didalam meng-upayakan pengembangan potensi tersebut.

2. Mengingat mayoritas masyarakat bermatapencaharian di sektor pertanian, namun perlu meningkatkan nilai tambah sektor pertanian tersebut guna meningkatkan pendapatan masyarakat maupun daerah/wilayah tersebut.

3. Sektor primer masih menjadi sektor yang memberi kontribusi utama, oleh karena itu perlu diitegrasikan dengan sektor sekunder dan tersier. Hal ini supaya meningkatkan lapangan usaha disektor tersebut (sekunder dan tersier) dengan basis sektor primer.

4. Secara analisis statistik Anova tidak menunjukkan perbedaan profit antara produk organik dan non-organik. Namun produk organik lebih menguntungkan bagi lingkungan dan kesehatan . Dalam penelitian ini masih sebatas pada produk tertentu yaitu ikan nila,lele, lobster, sayur sawi dan telur. Dengan demikian perlu mengembangkan atau melakukan uji coba untuk produk-produk lainnya, sehingga produk organik lebih berkembang.

5. Sistem pertanian organik terpadu/integrited dengan prinsip minimisasi limbah dan efisiensi ekonomi merupakan model yang ideal. Oleh karena itu sistem tersebut perlu disebarluaskan kepada masyarakat luas dan perlu difasilitasi pihak terkait.

6. Perlu campur tangan pihak terkait di dalam saluran pemasaran. Selain itu untuk pasar di dalam negri perlu ingsosialisasi kepada masyarakat sebagai demand dan supply produk organik.

7. Mengingat penelitian ini terdapat keterbatasan dana dan waktu, maka perlu dilakukan penelitian lanjutan dengan menambah jumlah sampel.

\section{DAFTAR PUSTAKA}

Anonim, UUD 1945

Agustina, Lily, 2007, Sosial Ekonomi Pertanian Organik, makalah pengantar arahan organik, FP-UB Agustina, Lily, 2007, Sistem Produksi Sayuran Ternak Ikan Organik Berbasis Pada Limbah Organik, Laporan Progran Insentif Percepatan Difusi dan Pemanfaatan Iptek, Lembaga Penelitian UB - MenRistek R.I.

Arikunto S. 1997, Prosedur Penelitian ,Suatu Pendekatan Praktek, Rineka Cipta, Yogyakarta.

Choliq, Achsin Utami, Transfer Teknologi Pertanian Organik dalam Rangka Community Development, Proceeding Workshop MAPORINA, Jakarta.

Callan, Scoutt \& Thomas, Janet, 2000, Environmental Economics \& Management. Theory, Policy, and Applications, The Dryden Press, Harcourt College Publishers, USA

Fauzi, Akhmad, 2006, Ekonomi Sumberdaya Alam dan Lingkungan, Teori dan Aplikasi, Gramedia, Jakarta. 
Field \& Olewiler, 2002, Environmental Economics, McGraw-Hill, Canada

Lipsey, Richard,1995, Economics 10th ed, Harper \& Row

Riduan, 2009, Pengantar Statistik Sosial, Alfabeta, Bandung.

Tientenberg, Tom, 1996: “Enviromental Natural Resources Economics”.Harper Collins College Publishers

Sutanto R, 2002, Pertanian Organik, Menuju Pertanian Alternatif dan Berkelanjutan, Kanisius, Yogyakarta

Anonim 2005, Menghantarkan Indonesia Menjadi Produsen Organik Terkemuka, Proceeding Workshop MAPORINA, Jakarta.

Anonim, 2002, Memasyarakatan Pertanian Organik Sebagai Jembatan Menuju Pembangunan Pertanian Berkelanjutan. Prosiding Lokakarya Nasional Pertanian Organik, Malang

Salim,Wilmar, 2002 : Kemiskinan dan Ketimpangan Sosial di Indonesia : Persoalan dan alternative pemecahan,. Seminar Nasional Pemberdayaan Masyarakat Bagi Penanggulangan Kemiskinan: Sebuah Tantangan dalam Pembangunan Wilayah dan Kota, Kerjasama : ITB-SOCSEABAPPENAS

Suwantoro,Andreas Avelinus, 2008, Analisis Pengembangan Pertanian Organik di Kabupaten Magelang ( Studi Kasus di Kecamatan Sawangan), Tesis Program Magister Ilmu Lingkungan, Program Pasca Sarjana Universitas Diponeoro, Semarang 